\title{
PŘÍSPĚVEK K POZNÁNÍ HISTORIE HRADU U BORŠOVA NA MORAVSKOTŘEBOVSKU
}

\section{DAVID VÍCH}

Abstrakt: Hrad v k. ú. Boršov u Moravské Třbové spojuji písemné prameny s vojenskými událostmi z let 1285-1286. Detektorový průzkum okoli fortifikace prokázal dobývání hradu ve 13.-14. století. Prokázat se naopak nepodařilo spojitost hradu se zaniklou komunikaci probíhajíci prímo pod touto památkou.

Klíčová slova: vrcholný středověk - zaniklá cesta-hrad-hroty šipů.

\section{A contribution to the study of the history of a castle near Boršov, in the Moravská Třebová region}

Abstract: Written sources link the castle in the Boršov cadastral zone, near Moravská Třebová with military campaigns of 1285-1286. Metal-detector prospection in the surroundings of the fortification confirmed the siege of the castle in the 13th and 14th centuries. On the other hand, the connection between the castle and a defunct communication below it was not proved.

Key words: high Middle Ages - defunct track-castle - arrow tips.

Přibližně šest kilometrů západně od Moravské Třebové se v k. ú. Boršov u Moravské Třebové u osady Hřebeč nachází pozůstatky vrcholně středověkého opevnění (obr. 1). Neutěšený stav jeho dochování bohužel plně koresponduje se stavem poznání, i když pozornost byla této památce věnována již na počátku minulého století (Czerny 1910; později Weinelt 1937, 52-54). V letech 2016-2018 proběhl v rámci projektu Moravské křižovatky detektorový průzkum svahu pod touto lokalitou zaměřený na prospekci okolí zaniklé cesty pod hradem.

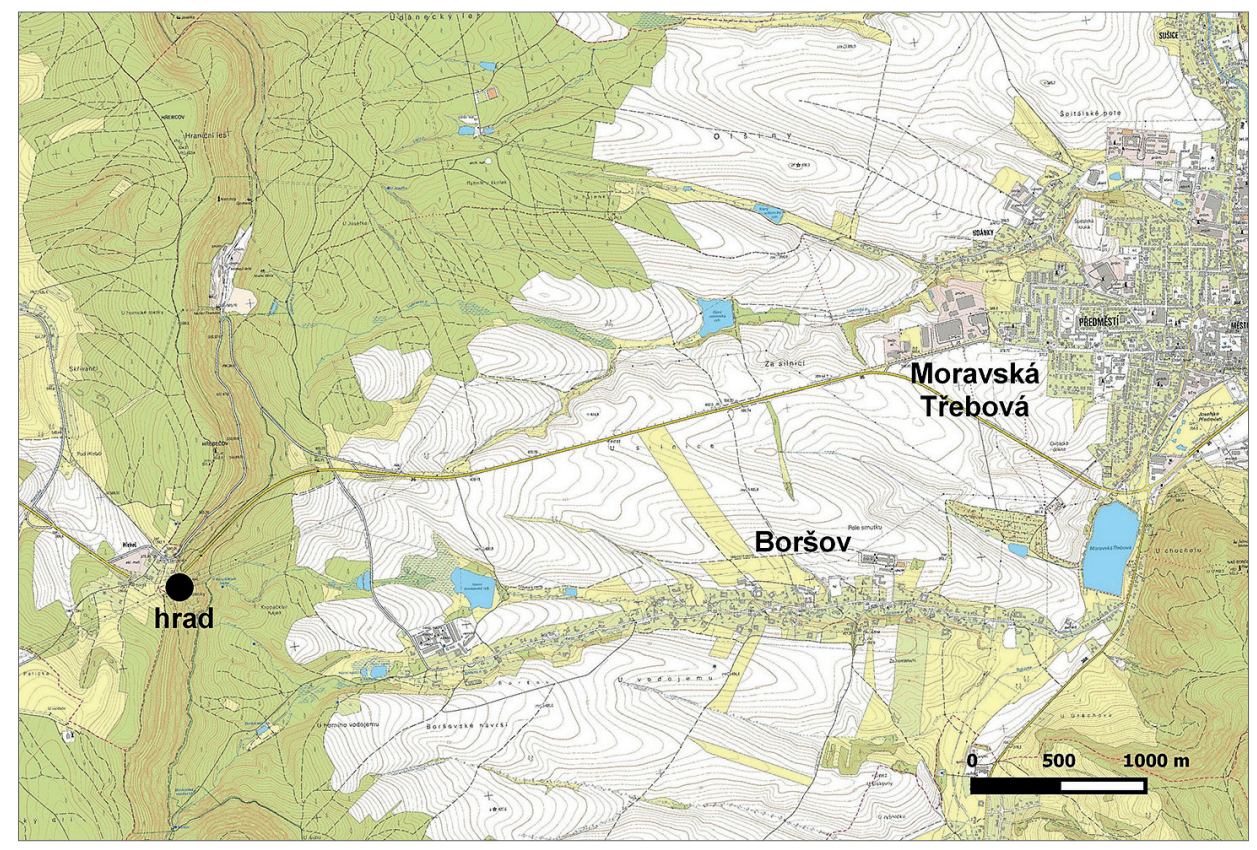

Obr. 1. Hrad v k. ú. Boršov u osady Hřebeč. Poloha lokality.

Abb. 1. Burg im Katastergebiet Boršov an der Siedlung Hřebeč. Lage der Fundstelle. 
Počátky hradu se pojí s osídlováním Moravskotřebovska, přičemž kolonizace tohoto regionu proběhla někdy kolem poloviny 13. století (se starším osídlením z první poloviny 13. století, k problematice podrobně Bolina-Němcová-Šlézar 2008, 59-67) za Boreše z Riesenburku (k jeho osobě Velímský 2002, 69-86). Pro poznání osídlování Moravskotřebovska je důležitá zejména listina z roku 1267 týkající se obdarování kláštera Koruna Panny Marie v Třebařově tímto šlechticem (CDB V/2, 482 č. 796; k listině Velímský 2002, 76). K roku 1270 již byla podle výpovědi písemných pramenů hranice panství Boreše z Riesenburku stabilizovaná (Severin 2003, 190). Někdy před rokem 1285 za Fridricha mladšího ze Šumburka, poručníka dětí Boreše z Riesenburku, a z jeho popudu vznikl na hraně výrazného terénního zlomu poblíž vesnice Boršov (odrážející ve svém označení jméno Boreše z Riesenburku) na území nárokovaném olomouckým biskupem hrad. Neoprávněnou stavbu řešila arbitráž mezi Fridrichem ze Šumburka a olomouckým biskupem Dětřichem z Hradce (RMB II, 583-585 č. 1353). Podle jiného pramene (RBM II, 1006-1007 č. 2321) mělo být z rozhodnutí krále Václava II. opevnění dokonce zbořeno. Že králova vůle nebyla naplněna, dokládá zpráva ze Zbraslavské kroniky, podle níž byla záhy (1285 či spíše 1286) zorganizována vojenská výprava a dobyta Moravská Třebová (FRB IV, 30). Obecně se předpokládá, že byl touto akcí zasažen také hrad nad vsí Boršov. Podle výpovědi archeologických pramenů touto událostí život na hradě nezanikl, nálezy keramiky dokládají zdejší aktivitu ještě později ve 14. století (Hampl 1970, 20; Nisler 2000, 11; Plaček 2001, 110; vyhodnocení i s vyobrazením nálezů Bolina-Němcová-Šlézar 2008, 55, obr. 3).

Samotný hrad byl vybudován na trojúhelníkovitém výběžku nad prudkým terénním zlomem (obr. 2). Areál hradu byl v 90. letech minulého století výrazně poničen zplanýrováním s pomocí buldozeru za účelem vztyčení stožárů elektrického napětí, terén dnes po značnou část roku skrývá neprostupná nízká vegetace. O podobě hradu nevíme nic, máme pouze informaci, že roku 1836 zde mělo dojít k odkrytí torza okrouhlé stavby považované za bergfrit (Czerny 1910, 40), údajně ověřené archeologickým výzkumem (Plaček 2001, 110). Hradní jádro oddělovala od okolí dvojice př́íkopů, z nichž je do dnešní doby dobře patrný již jen jeden. Po terénním hřbetu běžícím kolmo na terénní zlom směřuje pod hradní areál zbytek zaniklé cesty patrné v terénu jako dobře znatelný úvoz. V blízkosti hradu se cesta rozděluje, aby obešla přírodní překážku, posléze se zase spojuje (obr. 6).

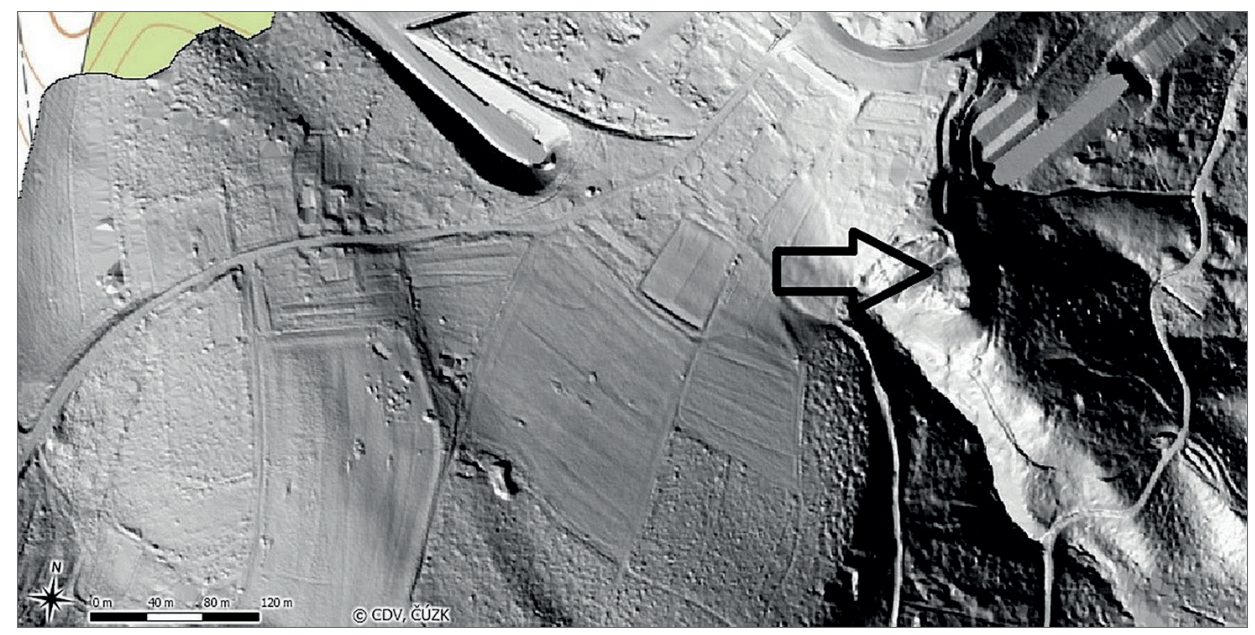

Obr. 2. Hrad v k. ú. Boršov u osady Hřebeč na LIDARovém snímku. Poloha hradu vyznačena šipkou. Stínovaný model reliéfu byl vytvořen na základě dat leteckého laserscaningu v rámci projektu Moravské křižovatky DG 16 PO2R031.

Abb. 2. Burg im Katastergebiet Boršov an der Siedlung Hřebeč auf einer LIDAR-Aufnahme Die Lage der Burg ist mit einem Pfeil gekennzeichnet. Schattenmodell des Reliefs erstellt anhand der mittels luftgestütztem Laserscanning im Rahmen des Projekts Mährische Kreuzungen DG 16PO2R031 gewonnenen Daten. 


\section{Soupis nálezů ${ }^{1}$}

\section{Hroty š́pů s trnem}

štíhlý hrot šípu s odkorodovaným trnem a tělem rombického prŕíčného průřezu, $67 \times 8 \times 6 \mathrm{~mm}$, hmotnost 7,8 g, E 0613844, N 5511606; hl. $18 \mathrm{~cm}$, z toho $13 \mathrm{~cm}$ ve sterilním podloží, azimut 320 (obr. 3:1)

štíhlý hrot šípu s odkorodovaným trnem a tělem rombického př́ičného průřezu, $63 \times 8 \times 7 \mathrm{~mm}$, hmotnost 8,1 g, E 0613928, N 5511605; nalezeno na povrchu v lesní hrabance (obr. 3:2)

štíhlý hrot šípu s odkorodovaným trnem a tělem rombického prríčného průřezu, $51 \times 6 \times 6 \mathrm{~mm}$, hmotnost 4,8 g, E 0613909, N 5511616; nalezeno na povrchu v lesní hrabance (obr. 3:3)

štíhlý hrot šípu s odkorodovaným trnem a tělem rombického př́ičného průřezu, $62 \times 8 \times 6 \mathrm{~mm}$, hmotnost 7,2 g, E 0613830, N 5511611; h1. 14 cm na rozhraní podloží a lesní humusové vrstvy (obr. 3:4)

štíhlý hrot šípu s odkorodovaným trnem a tělem rombického př́icného průřezu, $53 \times 7 \times 6 \mathrm{~mm}$, hmotnost 3,9 g, E 0613892, N 5511611; z rozhraní humusové vrstvy a podloží (obr. 3:5)

hrot šípu s částí trnu a tělem rombického příčného průřezu, $69 \times 12 \times 10 \mathrm{~mm}$, hmotnost $13,1 \mathrm{~g}$, E 0613912, N 5511625; předaný nález bez bližších údajů o hloubce, orientovaný hrotem do svahu směrem $\mathrm{k}$ hradu (obr. 3:6)

hrot šípu se zcela odkorodovaným trnem a tělem rombického příčného průřezu, $57 \times 12 \times 9 \mathrm{~mm}$, hmotnost 16,3 g, E 0613806, N 5511609; hl. 5 cm v humusové vrstvě, azimut $340^{\circ}$ (obr. 3:7)

štíhlý hrot šípu $\mathrm{s}$ částečně odkorodovaným trnem a tělem rombického př́ičného průřezu, $72 \times 8 \times 8 \mathrm{~mm}$, hmotnost 9,8 g, E 0613870, N 5511635; údaje o hloubce nedochovány, azimut $240^{\circ}$ (obr. 3:8)

štíhlý hrot šípu se zcela odkorodovanou bazí a tělem rombického příčného průřezu, $40 \times 12 \times 11 \mathrm{~mm}$, hmotnost 7,7 g, E 0613859, N 5511604; hl. $28 \mathrm{~cm}$, z toho $2 \mathrm{~cm}$ ve sterilním podloží, azimut $90^{\circ}$ (obr. 3:9)

masivní hrot šípu s odkorodovaným trnem a tělem rombického př́íčného průřezu, $73 \times 15 \times 13 \mathrm{~mm}$, hmotnost 27,1 g, E 0613839, N 5511626; hl. $17 \mathrm{~cm}$, z toho $10 \mathrm{~cm}$ ve sterilním podloží hrotem do země (obr. 3:13)

štíhlý hrot šípu s částečně odkorodovaným trnem a tělem rombického př́ičného průřezu, $66 \times 8 \times 6 \mathrm{~mm}$, hmotnost $6,0 \mathrm{~g}$, E 0613852 , N 5511595; hl. $16 \mathrm{~cm}$ na rozhraní humusové vrstvy a podloží (obr. 3:11)

štíhlý hrot šípu s odkorodovaným trnem a tělem rombického příčného průřezu, $54 \times 7 \times 4 \mathrm{~mm}$, hmotnost 5,0 g, E 0613871, N 5511598; hl. $7 \mathrm{~cm}$, z toho $2 \mathrm{~cm}$ ve sterilním podloží (obr. 3:10)

1 Uváděné rozměry byly měřeny po konzervaci, souřadnice jsou v UTM, měřené ruční stanicí GPS značky Garmin Etrex 20. Pokud je uveden azimut, udává směr, kam hrot míŕil špičkou. Koroze a následná konzervace jsou př́ičinou nepř́iliš přesvědčivého tvaru na kresbách, stav před konzervací ale nenechává prostor pro pochyby, že jde o hroty šípů. Všechny nálezy jsou uloženy v Regionálním muzeu v Litomyšli. 

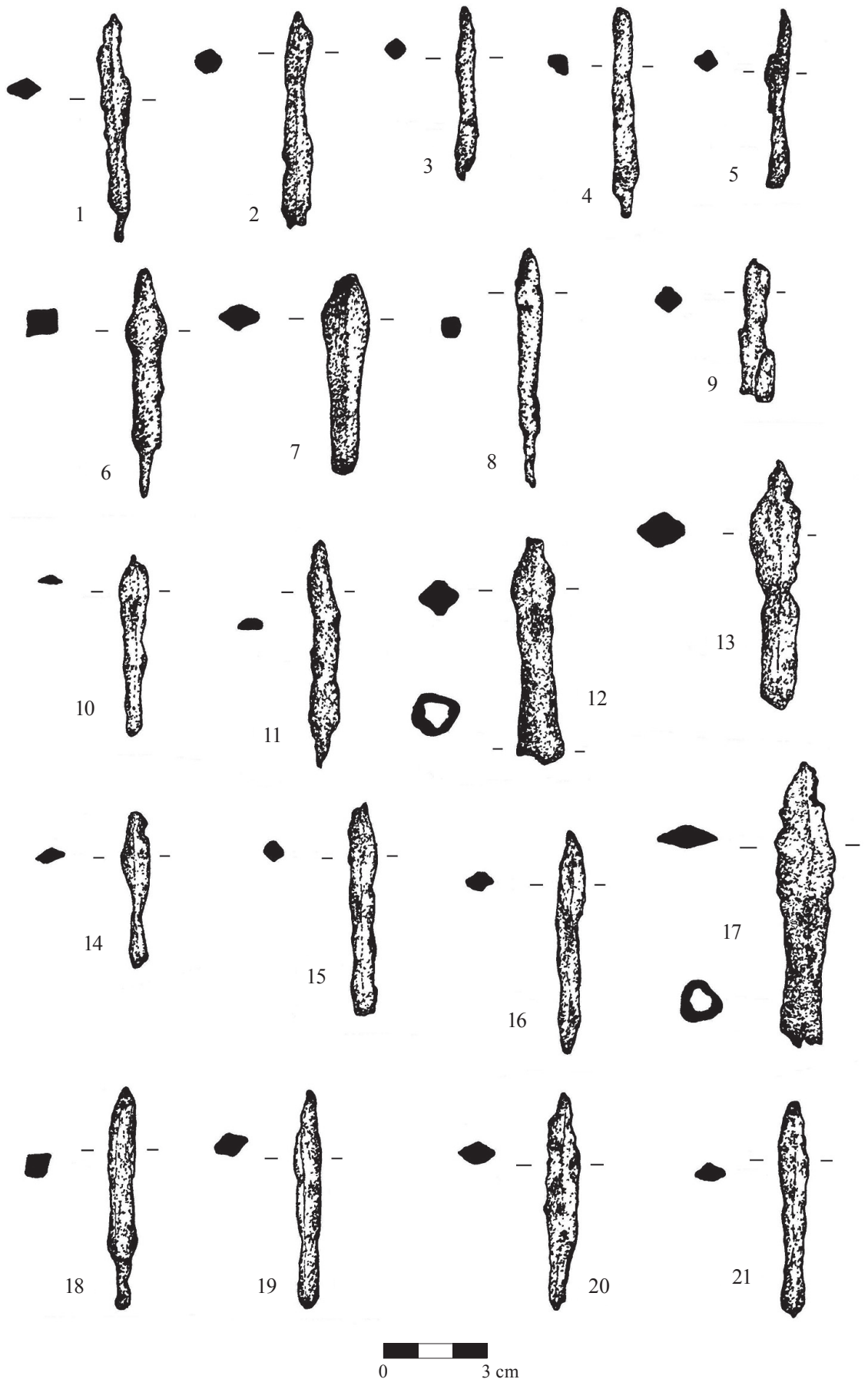

Obr. 3. Boršov u Moravské Třebové. Nálezy ze svahů hradu. Kresba Alžběta Hronová.

Abb. 3. Boršov bei Moravská Třebová. Funde vom Burghang. Zeichnung Alžběta Hronová. 
velmi subtilní hrot šípu s odkorodovaným trnem a tělem rombického prř́čného průřezu, $45 \times 9 \times 5 \mathrm{~mm}$, hmotnost 4,5 g, E 0613929, N 5511614; hl. 26 cm, z toho 18 cm ve sterilním podloží (obr. 3:14)

štíhlý hrot šípu se zcela odkorodovaným trnem a tělem rombického příčného průřezu, $62 \times 8 \times 7 \mathrm{~mm}$, hmotnost 8,8 g, E 0613788, N 5511620; hl. 10 cm v lesní humusové vrstvě (obr. 3:15)

štíhlý hrot šípu s odkorodovaným trnem a tělem rombického př́icného průřezu, $64 \times 9 \times 7 \mathrm{~mm}$, hmotnost 8,9 g, E 0613911, N 5511618; hl. $20 \mathrm{~cm}$, z toho $10 \mathrm{~cm}$ ve sterilním podloží, azimut $220^{\circ}$ (obr. 3:16)

štíhlý hrot šípu $\mathrm{s}$ částečně odkorodovaným trnem a tělem rombického př́ičného průřezu, $65 \times 9 \times 8 \mathrm{~mm}$, hmotnost 11,1 g, E 0613949, N 5511573; hl. 8 cm na rozhraní lesní humusové vrstvy a podloží, azimut $120^{\circ}$ (obr. 3:18)

štíhlý hrot šípu se zcela odkorodovaným trnem a tělem rombického př́ičného průřezu, $64 \times 9 \times 7$ mm, hmotnost 9,1 g, E 0613898 , N 5511634; hl. $14 \mathrm{~cm}, \mathrm{z}$ toho $3 \mathrm{~cm}$ ve sterilním podloží, azimut $250^{\circ}$ (obr. 3:19)

štíhlý hrot šípu se zcela odkorodovanou bazí a tělem rombického příčného průřezu, $63 \times 10 \times 6 \mathrm{~mm}$, hmotnost 8,3 g, E 0613922, N 5511633; hl. $12 \mathrm{~cm}$, z toho $7 \mathrm{~cm}$ ve sterilním podloží, azimut $60^{\circ}$ (obr. 3:20)

štíhlý hrot šípu s odkorodovaným trnem a tělem rombického př́ičného průřezu, $63 \times 8 \times 7 \mathrm{~mm}$, hmotnost 7,7 g, E 0613904, N 5511606; hl. $24 \mathrm{~cm}$, z toho $13 \mathrm{~cm}$ ve sterilním podloží, azimut 105 (obr. 3:21)

štíhlý hrot šípu se zcela odkorodovaným trnem a tělem rombického příčného průřezu, $70 \times 11 \times 8 \mathrm{~mm}$, hmotnost 13,6 g, E 0613925 , N 5511613; hl. $13 \mathrm{~cm}$, z toho $5 \mathrm{~cm}$ ve sterilním podloží, azimut $320^{\circ}$ (obr. 4:1)

štíhlý hrot šípu s odkorodovaným trnem a tělem rombického př́ičného průřezu, $69 \times 9 \times 6 \mathrm{~mm}$, hmotnost 9,4 g, E 0613806, N 5511673; hl. 2 cm v humusové vrstvě, azimut $10^{\circ}$ (obr. 4:2)

štíhlý hrot šípu se zcela odkorodovaným trnem a tělem rombického příčného průřezu, $57 \times 10 \times 7 \mathrm{~mm}$, hmotnost 6,8 g, E 0613813, N 5511631; hl. $3 \mathrm{~cm}$ v humusové vrstvě, azimut $80^{\circ}$ (obr. 4:3)

štíhlý hrot šípu se zcela odkorodovanou bazí a tělem rombického př́ičného průřezu, $72 \times 10 \times 8 \mathrm{~mm}$, hmotnost 13,1 g, E 0613955, N 5511579; hl. 5 cm v humusové vrstvě, azimut $240^{\circ}$ (obr. 4:4)

štíhlý hrot šípu se zcela odkorodovaným trnem a tělem rombického př́ičného průř̌ezu, $60 \times 10 \times 7 \mathrm{~mm}$, hmotnost 7,2 g, E 0613914, N 5511619; hl. $10 \mathrm{~cm}$, z toho $5 \mathrm{~cm}$ ve sterilním podloží, azimut $310^{\circ}$ (obr. 4:10)

štíhlý hrot šípu se zcela odkorodovaným trnem a tělem rombického př́ičného průřezu, $63 \times 10 \times 8 \mathrm{~mm}$, hmotnost 10,0 g, E $0613903, \mathrm{~N} 5511663 ; \mathrm{hl} .20 \mathrm{~cm}, \mathrm{z}$ toho $18 \mathrm{~cm}$ ve sterilním podloží, trnem kolmo do země, hrotem vzhưru (obr. 4:6)

extrémně dlouhý štíhlý hrot šípu s odkorodovaným trnem a tělem rombického př́ičného průřrezu, $103 \times 7 \times 6 \mathrm{~mm}$, hmotnost 8,4 g, E 0614361, N 5511224; hl. $21 \mathrm{~cm}, \mathrm{z}$ toho $15 \mathrm{~cm}$ ve sterilním podloží (obr. 4:12) 


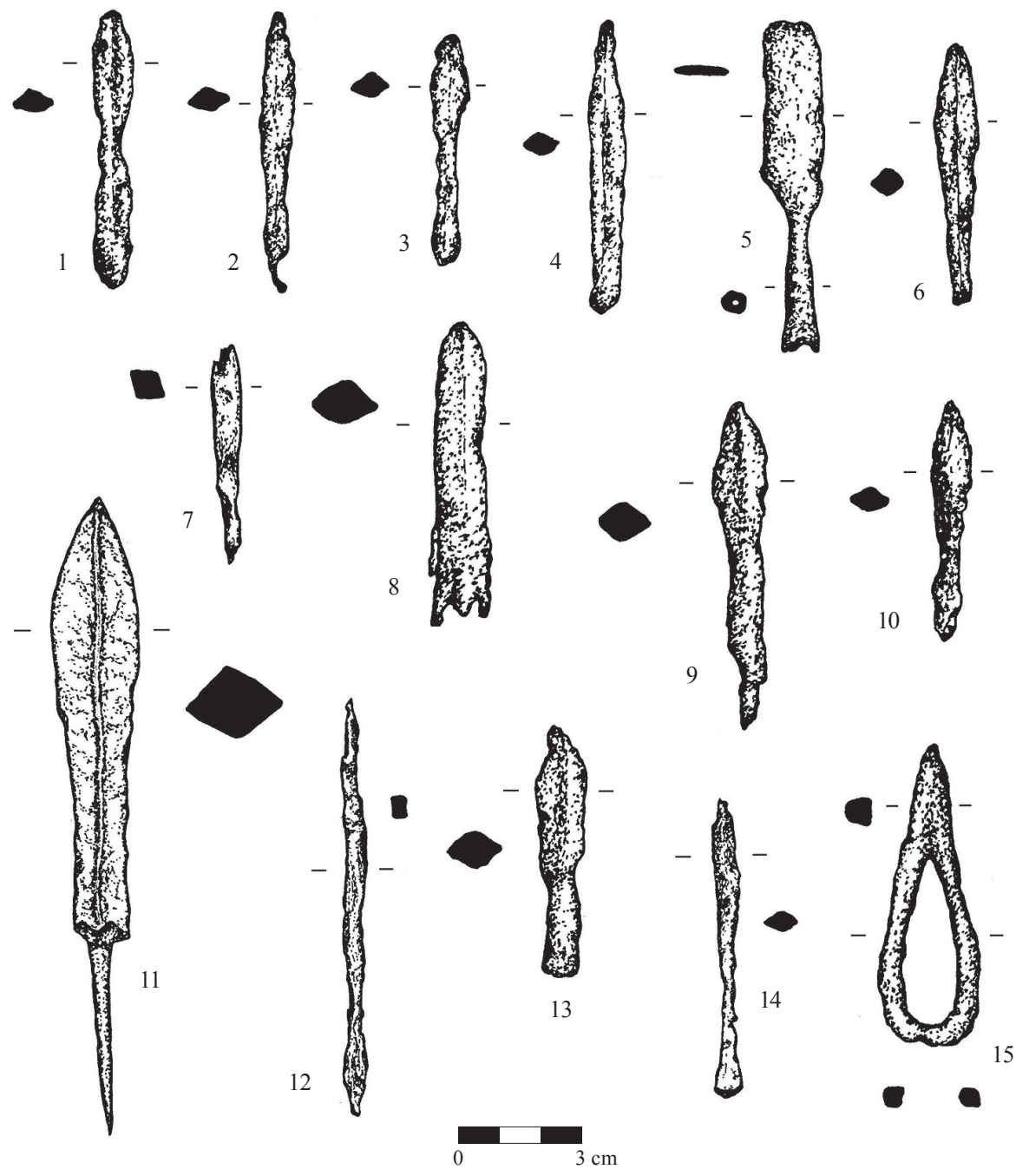

Obr. 4. Boršov u Moravské Třebové. Nálezy ze svahů hradu. Kresba Alžběta Hronová.

Abb. 4. Boršov bei Moravská Třebová. Funde vom Burghang. Zeichnung Alžběta Hronová.

hrot šípu se zcela odkorodovaným trnem a tělem rombického př́ičného průřezu, $63 \times 13 \times 10 \mathrm{~mm}$, hmotnost 18,4 g, E 0613900, N 5511612; hl. $15 \mathrm{~cm}$, z toho $8 \mathrm{~cm}$ ve sterilním podloží, azimut $320^{\circ}$ (obr. 4:13)

hrot šípu s částečně odkorodovaným trnem a tělem rombického př́ičného průřrezu, $83 \times 13 \times 10 \mathrm{~mm}$, hmotnost 20,7 g, E 0613997, N 5511580; hl. $12 \mathrm{~cm} \mathrm{z}$ toho $2 \mathrm{~cm}$ ve sterilním podloží, azimut $150^{\circ}$ (obr. 4:9) 
extrémně masivní hrot šípu s trnem rombického příčného průřezu, $157 \times 23 \times 17 \mathrm{~mm}$, hmotnost 117,5 g, E 0613787, N 5511607; hl. 5 cm v lesní hrabance, zjevně pohozený nález z nelegálního detektorového průzkumu (obr. 4:11)

štíhlý hrot šípu s odkorodovaným trnem a tělem rombického př́ičného průřezu, $73 \times 8 \times 8 \mathrm{~mm}$, E 0613852, N 5511625; hl. 16 cm na rozhraní lesní humusové vrstvy a sterilního podloží (obr. 4:14)

štíhlý hrot šípu se zcela odkorodovanou bazí a tělem rombického př́ičného průřrezu, $54 \times 10 \times 8 \mathrm{~mm}$, hmotnost 7,4 g, E 0613840, N 5511611; hl. 15 cm v lesní humusové vrstvě (obr. 4:7)

\section{Hroty šípů s tulejí}

hrot šípu s částečně odkorodovanou tulejí a tělem rombického příčného průřezu, $65 \times 11 \times 11 \mathrm{~mm}$, hmotnost 22,5 g, E 0613895, N 5511602; hl. $12 \mathrm{~cm}$, z toho $6 \mathrm{~cm}$ ve sterilním podloží, azimut $260^{\circ}$ (obr. 3:12)

hrot šípu s částečně odkorodovanou tulejí a tělem ploše rombického př́ičného průřrezu, $84 \times 18 \times 12$ mm, hmotnost 29,7 g, E 0613940, N 5511588; hl. 8 cm na rozhraní lesní humusové vrstvy a sterilního podloží, azimut $300^{\circ}$ (obr. 3:17)

hrot šípu se subtilní tulejí a plochým listovitým tělem ploše bikonvexního příčného průřezu, $84 \times 15 \times 7 \mathrm{~mm}$, hmotnost 8,0 g, E 0614094, N 5511501; hl. $26 \mathrm{~cm}$, z toho $19 \mathrm{~cm}$ ve sterilním podloží, azimut $290^{\circ}$ (obr. 4:5)

hrot šípu s částečně odkorodovanou tulejí a tělem rombického příčného průřezu, $15 \times 16 \mathrm{~mm}$, hmotnost 29,4 g, E 0614205, N 5511444; údaje o hloubce nedochovány, azimut 180 (obr. 4:8)

\section{Ostatní}

polovina stíhlového udila, $76 \times 40 \times 24 \mathrm{~mm}$ (v zakorodovaném stavu), hmotnost 23,2 g, E 0613838 , N 5511611; nalezeno v lesní hrabance (obr. 5:2)

udítko ze stíhlového udidla, $80 \times 22 \times 8 \mathrm{~mm}$, hmotnost 18,5 g, E 0614419, N 5511274; z ornice na poli (obr. 5:3)

čepel většího nože či tesáku, $220 \times 34 \times 5$ mm, hmotnost 67,0 g, E 0613831, N 5511588; nalezeno pohozené u paty stromu jako pozůstatek nelegálních detektorových aktivit (obr. 5:6)

torzo ostruhy s obloukovitě prohnutými rameny a dlouhým vidlicovitým bodcem, přičemž koncová část vidlice s kolečkem chybí, $92 \times 130 \times 32$ mm, hmotnost 36,8 g, E 0614225, N 5511370; hl. $8 \mathrm{~cm}$ na rozhraní lesní humusové vrstvy a sterilního podloží (obr. 5:1)

ostruha s rovnými rameny, na jednom z původních odlomených konců je patrný zbytek výrazného zalomení, v krátké prohnuté vidlici dochován zbytek kolečka, $100 \times 92 \times 23 \mathrm{~mm}$, hmotnost $30,9 \mathrm{~g}$, E 0614236, N 5511387; hl. 5 cm v lesní hrabance (obr. 5:4)

zákolník s rozšířenou týlovou částí, $114 \times 36 \times 18$ mm, hmotnost 110,4 g, E 0613985, N 5511481; hl. $22 \mathrm{~cm}$ na rozhraní lesní humusové vrstvy a sterilního podloží (obr. 5:5)

ocílka mandlovitého tvaru, $75 \times 24 \times 7$ mm, hmotnost 19,1 g, E 0614445, N 5511302; z ornice na poli (obr. 4:15) 

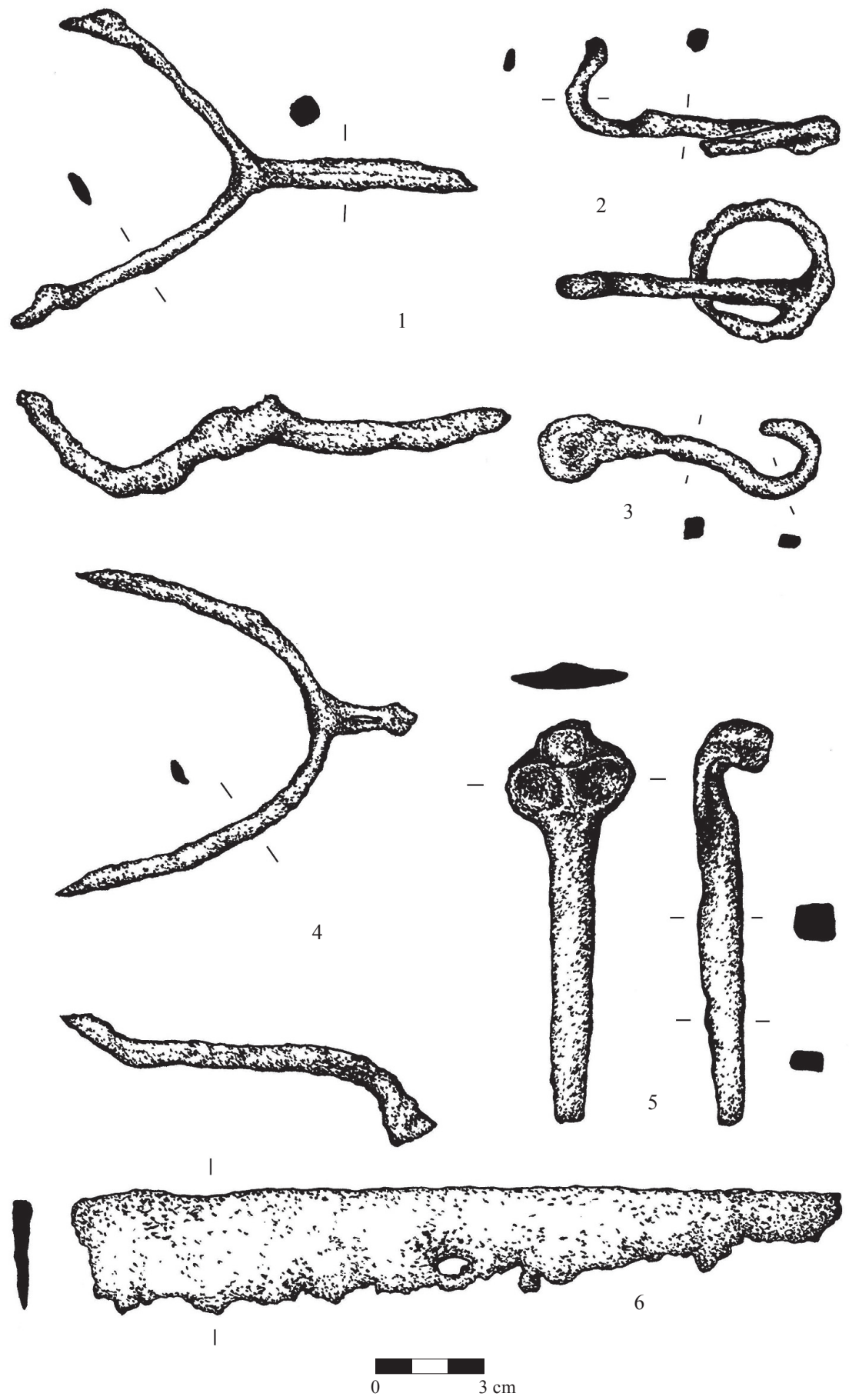

Obr. 5. Boršov u Moravské Třebové. Nálezy ze svahů hradu. Kresba Alžběta Hronová.

Abb. 5. Boršov bei Moravská Třebová. Funde vom Burghang. Zeichnung Alžběta Hronová. 
Z celkového počtu 42 prezentovaných předmětů tvoří naprostou většinu ( $35 \mathrm{ks}, 83$ \%) hroty šípů nacházené na svazích bezprostředně pod hradem. Z nich naprostá většina náleží $\mathrm{k}$ šípům připevňovaným na ratiště pomocí trnu.

Všechny hroty s trnem (pokud stav dochování dovoluje posoudit) můžeme přiřadit $\mathrm{k}$ typu Alb podle T. Durdíka (1972, 5, obr. 2), A II podle R. Krajíce (2003, 186, obr. 150), B 11 podle A. Ruttkaye $(1976,327$, obr. 54) či D 2-4, respektive D 2-5 podle B. Zimmermanna (2000, 75-76, tab. 24-25). Daný typ hrotů se v západních částech Evropy objevuje pravděpodobně již v průběhu 10.-12. století, přičemž jeho nejmasovější výskyt je spatřován v období 13.-14. století (Zimmermann 2000, 75; Žákovský-Hošek 2015, 229). Také na území České republiky se tyto hroty objevují především na lokalitách z 13.-14. století (např. Hradišt'ko u Davle - Richter 1982, 165; hrad Freudenštejn - Kouřil 1997, 389, obr. 4:1-6; Kouřil-Prix-Wihoda 2000, 88, obr. 53-55; hrad Zkamenělý Zámek u Svratouchu - Adámek 1909, 26-28; tab. IX; Durdík 1983, 8-11, 18-19; k dataci lokality Frolík 1982, 17). Ještě na počátku 15. století se však podobné hroty uplatňovaly v masové míře, jak o tom svědčí např́íklad nálezy z hradu Javorník, které jsou spojovány s husitskými válkami (Kouřil 2009, 223-224, obr. 6), nebo nálezy ze Sezimova Ústí (Krajíc 2003, 187). Tyto hroty jsou vzhledem ke své konstrukci a hmotnosti považovány za hroty šípů určených ke střelbě z luku. V rámci této skupiny však přece jenom dva hroty poněkud vybočují. První z nich (obr. 4:12) se při zachování štíhlosti odlišuje abnormální délkou přesahující $100 \mathrm{~mm}$. Podobné hroty známe např́klad z hradů Freudenštejn (Kouřil 1997, 389, obr. 4:2), Bolkov (Hejna 1962, 462, obr. 4:2), Rokštejn (Měř́nský 2007, obr. 61:9) či Vízmburk (Koštál 2013, tabulka 71:23). Nedávno byl publikován nález z hradu Veselí nad Moravou datovaný archeologicky do druhé poloviny 13. století, přičemž se uvažuje o prodloužení těla hrotu za účelem přichycení zápalné

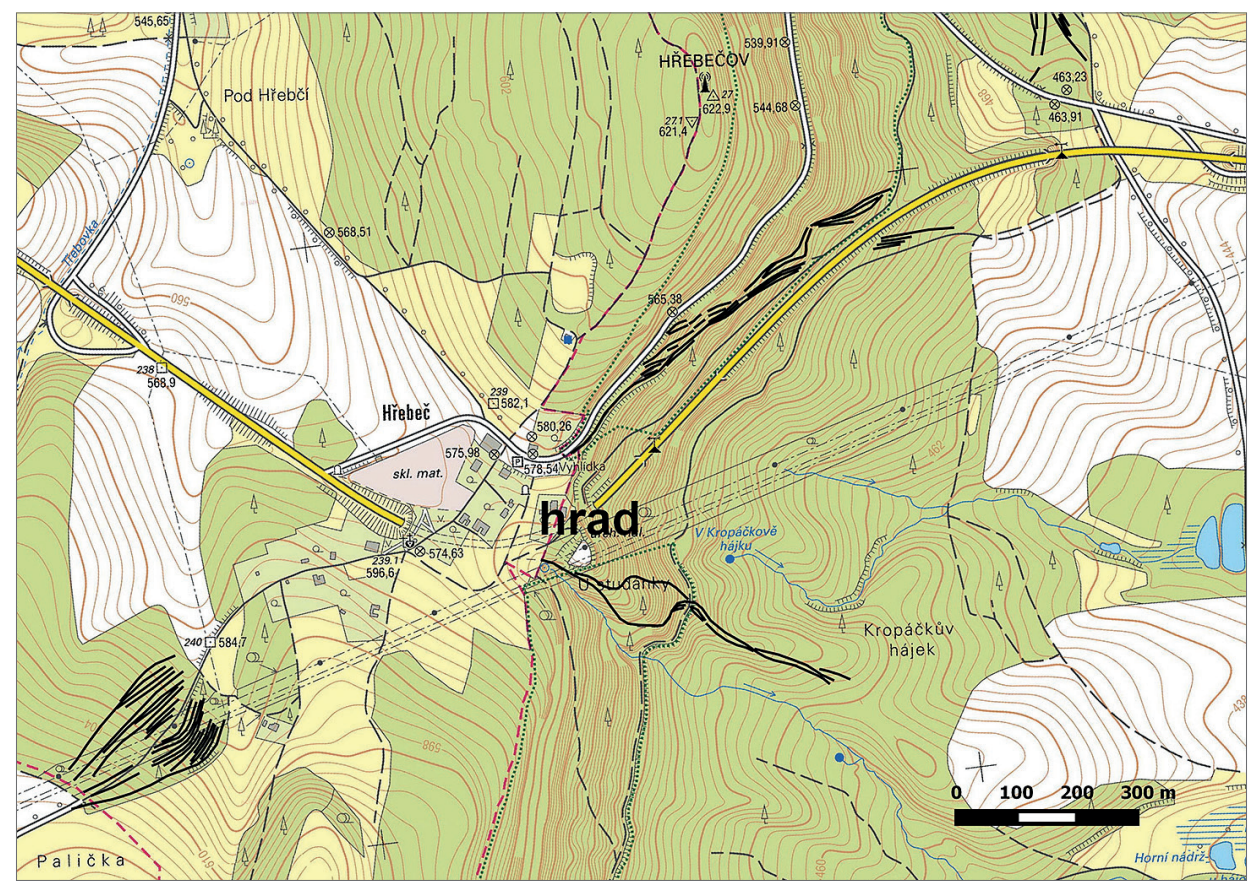

Obr. 6. Hrad v k. ú. Boršov u osady Hřebeč. Širší okolí lokality s vynesenými zaniklými cestami v podobě úvozů vyznačených černými liniemi. Průběh úvozů podle J. Martínka.

Abb. 6. Burg im Katastergebiet Boršov an der Siedlung Hřebeč. Die breitere Umgebung der Fundstelle mit in Form von mit schwarzen Linien gekennzeichneten Hohlwegen eingetragenen verschwundenen Wegen. Verlauf der Hohlwege nach J. Martínek. 
látky (Žákovský-Hošek 2015, 229). Hrot druhý (obr. 4:11) se při zachování formálního tvaru od zbývajících liší velkými rozměry, což nejlépe dokládá délka přes $15 \mathrm{~cm}$ a hmotnost převyšující 100 g. Posoudit využití takového zajisté specializovaného hrotu je dnes obtížné. Analogický a ještě větší kus ze Starého mesta v Banské Štiavnici archeologicky datovaný do 14. století je považován za hrot určený ke střelbě ze samostřílu (Labuda 2000, 16, obr. 5:5).

Polovina ze zastoupených tulejovitých hrotů, tj. dva kusy (obr. 3:17; 4:8), náleží k hrotům rombického prŕíčného průřezu typu B2a podle Durdíka (1972, 5, obr. 3); typu B IIb podle Krajíce (2003, 184, obr. 150) či typu T 2-5 podle Zimmermanna (2000, 51-53). V oblasti střední Evropy je jejich největší výskyt spatřován v průběhu 14.-15. století (např. Krajíc 2003, 187) v souvislosti s masovým rozšířením samostř́lů. Uvedenou dataci dokládá také řada početnějších nálezů z bývalého Československa, které jsou vázány na lokality spojené s husitskými či česko-uherskými válkami (např. Polla 1962, 136; Frolík 2002, 406; Novobilský 2008, 74-84; Kouřil 2009, 223-224, obr. 6). Jeden hrot (obr. 3:12) odpovídá svým štíhlejším tvarem a zřetelným zaškrcením těla typu T 2-4 (Zimmermann 2000, 49-50) či B IIa (Krajíc 2003, 184, obr. 150) se stejným datováním, jenom s poněkud časnějším nástupem (Zimmermann 2000, 50; Krajíc 2003, 187). Poslední hrot šípu vzhledem k subtilní tuleji a listovitému tělu (obr. 4:5) určený ke stř̌elbě z luku lze klasifikovat jako typ II (Nadolski 1954, 64), T5-4 (Zimmermann 2000, 61-63), A7a (Ruttkay 1976, 329) a B Ia (Krajíc 2003, obr. 150) s poměrně širokou datací do 9.-15. století s možným ojedinělým výskytem později (Slivka 1980, 239-240; Zimmermann 2000, 162; Krajíc 2003, 186), ale i dříve.

Ostruhy zastoupené dvěma exempláři patří obecně k chronologicky citlivějším předmětům. Datace ostruhy opatřené rovnými rameny ukončenými odsazenými úchyty (obr. 5:4) a prohnutou vidlicí je otevřená. Pokud nálezy poskytují nějakou datovací oporu (Beneš-Kubů-Török 1995, 466, obr. 6:2, 9:3; Chmielowiec-Kašpar 2014, 410-413, 416), jde o ostruhy ze staršího novověku.

Druhá ostruha (obr. 5:1) se i přes torzovitý stav dochování vyznačuje ostře zalomenými rameny přibližně v poslední třetině své délky a dlouhou vidlicí. Ostruhy s dlouhou vidlicí se objevují od sklonku 14. století, především však v 15. století (Drobný 1995, 81; Krajíc 2003, 126; Koóšová 2004, 536). Uvedené závěry potvrzují analogické či podobné nálezy z hradu Rokštejna, kde minimálně jedna z ostruh pochází ze zánikového horizontu (Měřínský 1991, 74-75, obr. 5:2-3; 2007, 113, obr. 22, obr. 63:6, 8), a kartouzy v Dolanech (Burian 1982, 28). Podobné ostruhy pocházejí dále např́iklad z hradu Kaltenštejn (Brachtl 1995, 13, obr. 1:6) a z vojenského tábora u Klučova (Kudrnáč 1973, 122-123, obr. 14:5).

Ostatní artefakty jsou chronologicky zcela indiferentní. Prostá stíhlová udidla sestávající ze dvou udítek spojených kloubem a postranních kruhů dochovaná v torzech (obr. 5:2, 3) jsou klasifikovatelná jako typ I podle A. Nadolského (1954, 87), II podle A. Ruttkaye (1976, 357-358), IV podle A. N. Kirpičnikova (1973, 13-19; 1986, 108, tab. XVI) či 3 podle R. Krajíce $(2003,112)$ a patří k výrobkům využívaným od doby halštatské po novověk prakticky v nezměněné podobě. Chronologicky málo průkazné jsou rovněž ocílky mandlovitého tvaru (obr. 4:15) s analogiemi z hradu Devín (13.-16. století, Polla-Egyházy-Jurovská 1975, obr. 3:3), sekeřického hradiště (Vích 2018, 702, obr. 9:14), hradu Tekovská Breznica (15.-16. století, Budaj-Pírek 2017, 190, Tab. IV:5) a zákolníky (obr. 5:5), s nimiž se v publikovaných pramenech rovněž nesetkáváme často. Analogické zákolníky pochází z hradu Lopata (Novobilský 2008, 96, obr. 110:3/235, 4/233), zákolníky z hradu Vildštejn na Chrudimsku (Durdík-Frolík 1993, 58, obr. 17:5, 10) a Posádky pri Gajaroch (Polla 1962, 158, obr. 12:1, 4, 5, 7) mají jiný tvar hlavy.

Větší neprofilovaná čepel (obr. 5:6) představuje část masivního nože či spíše pozůstatek tesáku. Pokud by byla pravdivá druhá varianta, jednalo by se nejspíše o čepel typu A4 v pojetí P. Žákovského, s datací do vrcholného středověku až raného novověku (Žákovský 2014, 212).

Vzhledem k situování zaniklé komunikace do bezprostřední blízkosti hradu jsme při detektorovém průzkumu předpokládali vzájemnou časovou souvislost obou nemovitých památek. S artefakty vrcholně středověkého původu jsme se však setkávali především v úseku mezi vlastním hradem a moderní lesní cestou sledující vrstevnici prudkého svahu pod hradem ve vzdálenosti zhruba $200 \mathrm{~m}$ od něho. Jde především o hroty šípů, ojediněle se objeví čepel 
tesáku (?) a část udidla. ${ }^{2}$ Ve spodní části svahu pod moderní cestou sledující vrstevnici a na přilehlém poli pod svahem jsme objevili již pouze dvě ostruhy, zákolník, ojedinělé hroty šípů, udítko a ocílku mandlovitého tvaru. Vzhledem k tomu, že průzkum přinesl obrovské překvapení, totiž objev artefaktů z doby římské, je možné, že některé pouze intervalově datovatelné artefakty, které budou zveřejněny samostatně $\mathrm{s}$ nálezy doby římské, mohou být až vrcholně středověkého stáŕí, a naopak, části prezentovaných stíhlových udidel (a jeden hrot šípu) zde mohou naopak být teoreticky i starší. Každopádně v nálezovém spektru chybí některé artefakty charakteristické pro středověké komunikace, přičemž je nápadná především absence podkov. I další nálezy spojené s výstrojí jezdce a koně se vyskytují zcela ojediněle. Vysvětlení tohoto jevu hledáme jen obtížně. Pouze zcela hypoteticky mohl vznik hradu ukončit využivání této cesty a přesunout ji jinam. Severně od dnešní silnice č. 35 se nachází další úvozové cesty, v době našeho průzkumu však již nelegálně zcela „odkovené“ (obr. 6). Na jisté vrcholně středověké aktivity v tomto prostoru ukazuje nevelká kolekce železných předmětů objevená při hledání reálií z druhé světové války kolem serpentin, kterými stoupá tzv. stará silnice k osadě Hřebeč (Vích 2017a). Stejně hypotetické je využívání cesty vzhledem ke sklonu terénu určitým specifickým způsobem (např. pro pěší, tomu ale odporuje nález zákolníku), pravdu ale i pro postižení tohoto prostoru nelegálními detektorovými aktivitami asi již nikdy nezjistíme.

Jiné svědectví přinášejí hroty šípů. Jejich výskyt se koncentruje zřetelně do prostoru těsně pod hradem, přičemž jasně dominují štíhlé hroty šípů s trnem. Při průzkumu jsme, pokud to bylo možné, zachycovali orientaci hrotů pomocí azimutu, následné vynesení do mapy (obr. 7) ukazuje již zaznamenanou skutečnost, že převažuje orientace více méně kolmo na vrstevnice, přičemž ve

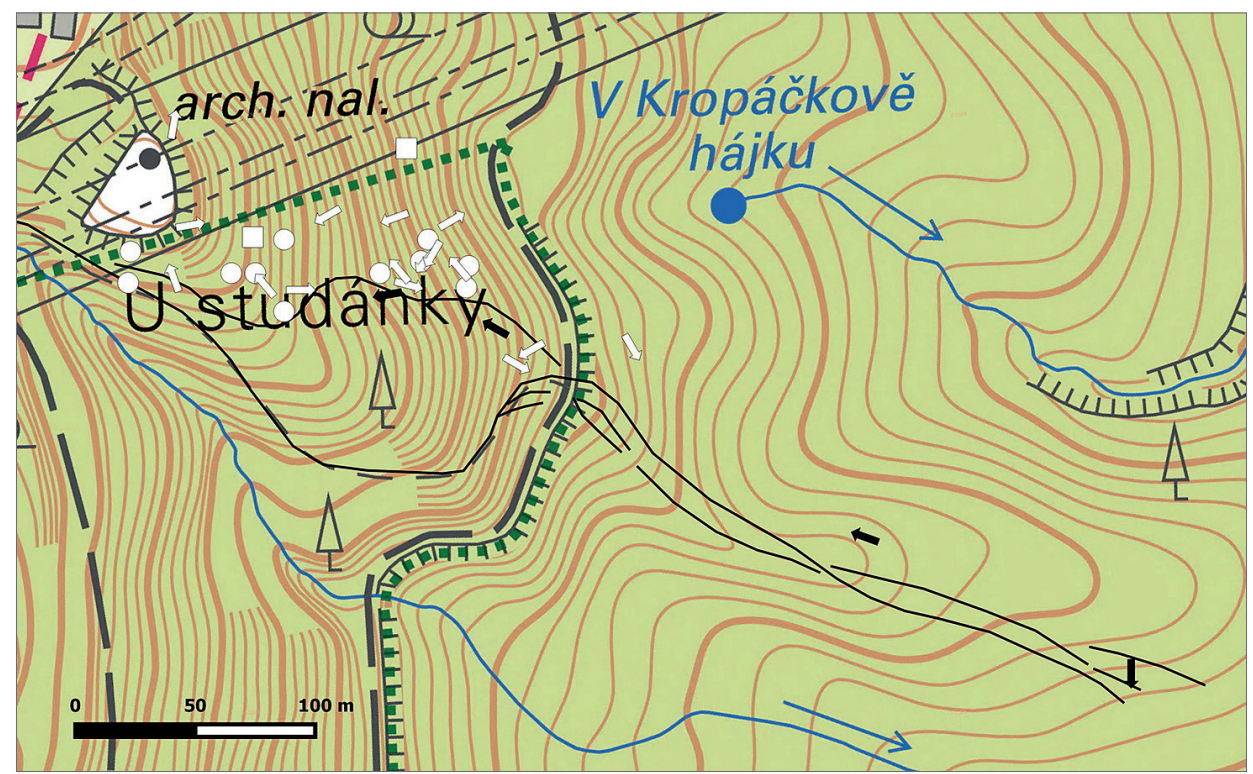

Obr. 7. Orientace hrotů šípů. Kolečko - orientace nezjištěna; čtvereček - hroty trnem či hrotem kolmo do země. Černě - hroty s tulejí; bíle - hroty s trnem. V programu Quantum GIS vytvořil autor.

Abb. 7. Pfeilspitzenrichtung. Kreis - Richtung nicht ermittelt; Quadrat - Pfeile mit dem Dorn bzw. mit der Spitze senkrecht in die Erde. Schwarz - Spitzen mit Tülle; weiß - Spitzen mit Dorn. Erstellt vom Verfasser mit der Software Quantum GIS.

$2 \mathrm{~V}$ této části jsme se rovněž setkávali s četnými a neklamnými známkami nelegálních detektorových aktivit v podobě vkopů a železných předmětů pohozených u stromů a pařezů. 
sledovaném souboru převažují hroty míŕící k hradu. Otázka, zda zjištěná orientace ukazuje směr střelby či zda je uložení šípu podélnou osou kolmo na svah způsobeno až vlivem postdepozičních procesů, zůstává otevřena (Vích 2017b). ${ }^{3}$ Bez ohledu na tuto skutečnost kumulace hrotů šípů (přičemž jejich počet rozhodně není konečný, řada dalších střel se nepochybně skrývá v neprostupném podrostu) a jejich rozptyl dokládá vojenskou událost spojenou s dobýváním hradu někdy ve 13. až starším úseku 14. století. Je tak možné, že vojenská akce, popisovaná Zbraslavskou kronikou k letům 1285-1286, namířená proti Fridrichu ze Šumburka se skutečně týkala i tohoto hradu, některé hroty (zejména masivní tulejovité hroty trapezovitého př́ičného průřezu) představují nejspíše mladší intruzi.

Prospekce okolí hradu v k. ú. Boršov známého díky bouřlivým událostem poslední čtvrtiny 13. století ukázala, že hrad mohl být v souvislosti s těmito událostmi skutečně dobýván. Překvapivější je skutečnost, že se nepodařilo prokázat př́mou vazbu hradu na zaniklou komunikaci dochovanou v terénu v podobě zahloubených úvozů přímo pod hradem.

\section{Prameny}

CDB V/2: Codex diplomaticus et epistolaris regni Bohemiae (Šebánek, J.-Dušková, S., edd.). Pragae 1981. FRB IV: Prameny dějin českých - Fontes rerum Bohemicarum (Emler, J., ed.). Praha 1884.

RBM II: Regesta diplomatica nec non epistolariaBohemiae et Moraviae (Emler, J., ed.). Pragae 1882.

\section{Literatura}

ADÁMEK, K. V., 1909: Perničky a Zkamenělý zámek, Zprávy Musea okresu hlineckého III, 3-30.

BENEŠ, J.-KUBŮ, F.-TÖRÖK, J., 1995: Soubor militarií z počátku třicetileté války z Volarských šancí, AR XLVII, 461-480.

BOLINA, P.-NĚMCOVÁ, J.-ŠLÉZAR, P., 2008: K počátkům hradů na Moravskotřebovsku - Zum Beginn der Burg in der Region Moravská Třebová (Mährisch Trübau), CB 11, 53-88.

BRACHTL, Z., 1995: Kovové a kostěné předměty z hradu Kaltenštejna. Fond muzea v Jeseníku a zámeckého muzea v Javorníku. Šumperk.

BUDAJ, M.-PÍREK, M., 2017: Nálezy zo 14.-15. storočia z hradu Tekovská Breznica - Funde vom 14.-15. Jahrhundert von der Burg Tekovska Breznica (Bez. Žarnovica), ZbSNM CXI - Archeológia 24, 179-193.

BURIAN, V., 1982: Jezdecké ostruhy posádek na Tepenci a Kartouzce, Zprávy Krajského vlastivědného muzea v Olomouci 218, 23-29.

CZERNY, A., 1910: Die Burg am Schönhengst, Mitteilungen zur Volkskunde des Schönhengster Lande VI, 39-48.

DROBNÝ, T., 1995: Vývoj středověkých ostruh od 11. do počátku 16. století. Nepublikovaná diplomová práce, ulož. v ÚAM FF MU, Brno.

DURDÍK, T., 1972: K problematice středověkých šipek v Československu, Zpravodaj klubu vojenské historie 2, 4-6; 3, 5-9.

- 1983: Středověké zbraně. Sbírky okresního muzea v Chrudimi. Historická řada 2/II. Chrudim.

DURDÍK, T.-FROLÍK, J., 1993: Hrad Vildštejn na Chrudimsku - Die Burg Vildštejn bei Chrudim, CB 3, 47-72. FROLÍK, J., 1982: Archeologické nálezy a minulost Skutečska. Skuteč.

- 2002: Nálezy z obléhání hradu Lichnice v letech 1428-1429 - Fundstoff aus der Belagerung der Burg Lichnice in den Jahren 1428-1429, CB 8, 399-408.

HAMPL, J., 1970: Hradiska našeho kraje, Moravskotřebovské vlastivědné listy 4, 17-21.

HEJNA, A., 1962: Soubor nálezů z hradu Bolkova v severovýchodních Čechách, PA LIII, 455-473.

3 Oproti hradu Zítkov, kde jsme azimut přidělovali až dodatečně podle slovního popisu, což nepochybně způsobilo jistou schematizaci, jsme poučeni praxí měřili orientaci hrotů přímo v terénu bezprostředně po objevu, pokud to bylo možné, ke zkreslení zde tedy již nedošlo. 
CHMIELOWIEC, S.-KAŠPAR, T., 2014: Vybrané kovové předměty ze studní na Staroměstském náměstí v Mladé Boleslavi, ASČ 18, 405-418.

KIRPIČNIKOV, A. N., 1973: Snarjaženije vsadnika i věrchovogo konja na Rusi IX-XIII vv. Archeologija SSSR, SAI E 1-36. Leningrad.

KOÓŠOVÁ, P., 2004: Ku klasifikácii vrcholnostredovekých ostrôh z územia Slovenska (12.-15. storočie) Zur Klassifikation der hochmittelalterlichen Sporen aus dem Gebiet der Slowakei (12.-15. Jahrhundert), AH 29, 523-547.

KOŠŤÁL, J. a kol., 2013: Vízmburk. Příběh ztraceného hradu. Havlovice.

KOUŘIL, P., 1997: Die Burg Freudenstein in Schlesien und ihr Hinterland. In: Život v archeologii středověku. Sborník př́ispěvků věnovaných Miroslavu Richterovi a Zdeňku Smetánkovi (Kubková, J.-Klápště, J.Ježek, M.-Meduna, P., edd.), 382-393. Praha.

- 2009: Hrad Javorník: březen 1428 - září 1434. Příspěvek k poznání hmotné kultury doby husitské ve Slezsku, ČSM B LVIII, 1-15.

KOUŘIL, P.-PRIX, D.-WIHODA, M., 2000: Hrady českého Slezska. Brno - Opava.

KRAJÍC, R., 2003: Sezimovo Ústí. Archeologie středověkého poddanského města 3. Kovárna v Sezimově Ústí a analýza výrobků ze železa. Praha - Sezimovo Ústí - Tábor.

KUDRNÁČ, J., 1973: Vojenský tábor z husitských válek v Klučově - Ein Militärlager aus der Zeit der Hussitenkriege in Klučov, PA LXIV, 105-142.

LABUDA, J., 2000: Pozoruhodné nálezy zo Starého mesta v Banskej Štiavnici - Beachtungswerte Funde aus „Staré mesto“ in Banská Štiavnica, AH 25, 7-24.

MĚŘÍNSKÝ,Z., 1991: Hrad Rokštejn a jeho úloha v předhusitském a husitském období. In: Sborník příspěvků k 555. výročí vyhlášení basilejských kompaktát v Jihlavě (Měřínský, Z., ed.), 65-82. Brno - Jihlava.

- 2007: Hrad Rokštejn. Dějiny, stavební vývoj a výsledky čtvrtstoletí archeologického výzkumu 1981-2006. Brtnice - Brno.

NADOLSKI, A., 1954: Studia nad uzbrojeniem polskim w X, XI i XII wieku. Łódź.

NISLER, P., 2000: „Vytunelovaný“ hrad, Moravskotřebovské vlastivědné listy 11, 10-13.

NOVOBILSKÝ, M., 2008: Obléhaní hradu Lopaty. Rekonstrukce obléhání hradu z roku 1432-1433. Plzen̆.

PLAČEK, M., 2001: Ilustrovaná encyklopedie moravských hradů, hrádků a tvrzí. Praha.

POLLA, B., 1962: Pamiatky hmotnej kultúry 15. storočia z Posádky pri Gajaroch, ZbSNM LVI-História 2, $107-140$.

POLLA, B.-EGYHÁZY-JUROVSKÁ, B., 1975: Stredoveké pamiatky hmotnej kultúry z archeologických výskumov na devínskom hrade, ZbSNM LXIX - História 15, 97-168.

RICHTER, M., 1982: Hradišt'ko u Davle. Městečko ostrovského kláštera. Praha.

RUTTKAY, A., 1976: Waffen und Reiterausrüstung des 9. bis zur ersten Hälfte des 14. Jahrhunderst in der Slowakei, SlArch XXIV, 245-395.

SEVERIN, K., 2003: Kolonizace Hřebečska - Die Kolonisation von Schönhengsten, AH 28, 175-210.

SLIVKA, M., 1980: Stredoveké hutníctvo a kováčstvo na východnom Slovensku, 2. čast', Historica Carpatica $11,218-288$.

VELÍMSKÝ, T., 2002: Hrabišici, páni z Rýzmburka. Praha.

VÍCH, D., 2017a: Drobná kolekce železných předmětů z okolí silnice pod Hřebčí u Moravské Třebové, AVČ 11 (2016), 180-184.

- 2017b: Projectile head finds from Zítkov Castle near Choceň, Acta Militaria Mediaevalia XIII, 83-109.

- 2018: Kolekce kovových předmětů předaná do Regionálního muzea ve Vysokém Mýtě, ASČ 22, 687-707.

WEINELT, H., 1937: Grundriß der Schönhengster Burgenkunde, Mitteillungen zur Volks- und Heimatkunde des Schönhengster Landes 33, 1-87.

ZIMMERMANN, B., 2000: Mittelalterliche Geschossspitzen. Kulturhistorische, archäologische und archäometallurgische Untersuchengen. Schweitzer Beiträge zur Kulturgeschichte und Archäologie des Mittelalters 26. Basel.

ŽÁKOVSKÝ, P., 2014: Tesáky a problematika jednosečných zbraní středověku a raného novověku. Nepublikovaná disertační práce, ulož. v ÚAM FF MU, Brno.

ŽÁKOVSKÝ, P.-HOŠEK, J., 2015: Kovové artefakty. In: Veselí nad Moravou. Stř̌edověký hrad v říční nivě, 220-251. Brno. 


\section{Zusammenfassung}

\section{Ein Beitrag zur Geschichte der Burg bei Boršov in der Region Moravská Třebová}

Ungefähr sechs Kilometer westlich von Moravská Třebova befinden sich im Katastergebiet Boršov bei Moravskà Třebovà an der Siedlung Hřebeč die Überreste einer hochmittelalterlichen Befestigungsanlage (Abb. 1). Die Anfänge der Burg hängen mit der Besiedelung der Region Moravská Třebová zusammen, wobei die Kolonisation dieser Region irgendwann um Mitte des 13. Jahrhunderts unter Boresch von Riesenburg erfolgte. Irgendwann vor 1285 entsteht unter Friedrich d.J. von Schönburg am Rand eines ausgeprägten Geländebruchs in der Nähe des Dorfes Boršov auf einem vom Olmützer Bischof beanspruchten Stück Land eine Burg. Der unrechtmäßige Bau wurde von einem Schiedsgericht zwischen Friedrich von Schönburg und dem Olmützer Bischof Theoderich von Neuhaus verhandelt. Nach einer anderen Quelle sollte die Befestigungsanlage auf Beschluss von König Wenzel II. sogar abgerissen werden. Dass der Wille des Königs nicht erfüllt wurde, belegt ein Bericht in der Königsaaler Chronik, wonach bald ein Feldzug organisiert und Moravská Třebová eingenommen wurde. Allgemein nimmt man an, dass von dieser Maßnahme auch die Burg oberhalb des Dorfes Boršov betroffen war.

Die Burg selbst wurde auf einem dreieckigen Ausläufer oberhalb des steilen Geländebruchs errichtet. Der Burgkern wurde durch zwei Gräben von der Umgebung abgetrennt, von denen nur einer heute noch gut erkennbar ist (Abb. 6). Unter dem über den Bergrücken verlaufenden Burgareal verlaufen quer zum Geländebruch die Reste eines verschwundenen Weges, der im Gelände als gut erkennbarer Hohlweg sichtbar ist. In der Nähe der Burg gabelt sich der Weg, um ein natürliches Hindernis zu umgehen und um schließlich wieder zusammenzulaufen. (Abb. 2).

Von insgesamt 42 präsentierten Gegenständen (Abb. 3-5) sind durchaus die meisten (35 Stück) Pfeilspitzen, die in den sich unmittelbar unter der Burg befindenden Hängen gefunden wurden. Die durchaus meisten von ihnen gehören zu Pfeilen, die mit einem Dorn am Schaft befestigt wurden. Diese Spitzen fanden auf tschechischem Territorium besonders im 13.-14. Jahrhundert Verwendung. Während die Sporen (Abb. 5:1, 4) in das 15. Jahrhundert und in die Neuzeit datiert werden, ist die Klinge eines Messers oder Jagdmessers (Abb. 5:6), Teile von Trensen (Abb. 5:2, 3), ein Wetzstahl (Abb. 4:15) und ein Arretiernagel (Abb. 5:5) chronologisch mehr oder weniger irrelevant.

Im Hinblick darauf, dass der verschwundene Verkehrsweg in unmittelbarer Nähe zur Burg angelegt wurde, haben wir bei der Detektorsuche einen gemeinsamen zeitlichen Zusammenhang beider unbeweglichen Denkmäler angenommen. Artefakten hochmittelalterlichen Ursprungs (vor allem Pfeilspitzen) sind wir jedoch vor allem in dem Abschnitt zwischen der eigentlichen Burg und dem modernen Waldweg begegnet, welcher der Höhenlinie des Steilhangs unterhalb der Burg folgt. Ein Zusammenhang zwischen dem verschwundenen Verkehrsweg und der Burg konnte so nicht nachgewiesen werden, eine große Überraschung hingegen war die Entdeckung von Funden aus der Römerzeit.

Ein anderes Zeugnis geben die Pfeilspitzen ab. Ihr Vorkommen konzentriert sich deutlich auf den dicht unterhalb der Burg liegenden Bereich, wobei schmale Pfeilspitzen mit Dorn klar dominieren. Bei der Untersuchung haben wir dort, wo dies möglich war, die Pfeilrichtung mittels Azimut erfasst und anschließend in die Karte eingetragen (Abb. 7), wodurch die bereits bemerkte Tatsache aufgezeigt wurde, dass eine mehr oder weniger quer zur Höhenlinie zeigende Richtung mit mehrheitlich auf die Burg gerichteten Spitzen überwiegt. Die Frage, ob die festgestellte Orientierung die Schussrichtung aufzeigt, oder ob die Lage der mit ihrer Längsachse quer zum Hang liegenden Pfeile erst durch den Einfluss postdepositärer Prozesse verursacht wurde, bleibt immer noch offen. Ungeachtet dieser Tatsache belegt die Anhäufung von Pfeilen und ihre Streuung ein mit einer irgendwann im 13. bis zum älteren Abschnitt des 14. Jahrhunderts erfolgten Einnahme der Burg verbundenes militärisches Ereignis. Es ist somit möglich, dass die in der Königsaaler Chronik zu den Jahren 1285-1286 beschriebene und gegen Friedrich von Schönberg gerichtete Militäroperation tatsächlich auch diese Burg betraf. 
Der vorliegende Beitrag wurde im Rahmen des Programmes zur Förderung der angewandten Forschung und Entwicklung der nationalen und kulturellen Identität (NAKI II) Nr. DG16P02R031 (Mährische Kreuzungen) ausgearbeitet.

PhDr. David Vích, Regionální muzeum ve Vysokém Mýtě, Šemberova 125, 56601 Vysoké Mýto; Centrum dopravního výzkumu, v. v. i., Líšeňská 33a, 63600 Brno, Česká republika,dvich@centrum.cz 
